\title{
The Memory of May '68: The Ironic Interruption and Democratic Commitment of the Atelier Populaire Clifford Deaton
}

\section{Introduction}

The space of Atelier Populaire produced a vivid iconography during the 1968 revolutionary movement in Paris. Some of these images demonstrate a tactic of ironic interruption, while others are dialectical images that evoke political memories of resistance, and the movement's democratic commitment as well. This paper traces the tactic of irony, along with the memory of resistance to the Algerian war during the early 1960s, arguing that both the social space of the Atelier itself and the political memories evoked in its posters shaped the revolutionary movement. Although the movement was unsuccessful in transforming the state, it did transform social space, opening up a terrain for the new social movements of the 1970s. Furthermore, the international memory of May '68 continues to influence contemporary revolutionary movements, including Occupy and the Arab Spring.

On May 15, 1968, students of the École des Beaux-Arts and the École Nationale Supérieure des Arts Décoratifs (Arts-Deco) occupied their campuses. Influenced by the outbreak of an earlier protest at Nanterre University and the Sorbonne, these art students participated in the growing revolutionary movement by occupying their schools and producing revolutionary posters. They called themselves the Atelier Populaire. The practices and posters developed by the Atelier are a window into the movement itself, its processes, and its imagination; although the manifestations of that May are now more than 40 years in the past, we can still access a deep well-

These two definitions of irony are drawn in large part from Webster's Dictionary.

2 For more on Benjamin's theory of the dialectical image, see Walter Benjamin, Illuminations (New York, NY: Harcourt Brace Jovanovich, 1968); Susan BuckMorss, The Dialectics of Seeing: Walter Benjamin and the Arcades Project (Cambridge, MA: MIT Press, 1991); and Isacc Balbus, Mourning and Modernity: Essays in the Psychoanalysis of Contemporary Society (New York, NY: Other Press, 2005). spring of revolutionary practice through the vividly remembered and reproduced, and often ironic, posters of the Atelier Populaire.

Any revolutionary movement can end ironically, with a combination of circumstances opposite of what is expected or for what is hoped. But perhaps no other such movement courted irony-as a method of humorous or sarcastic expression in which the intended meaning of the words used is the direct opposite of their usual sense-like the student revolutionaries of the Latin Quarter and their artistic allies at the Atelier Populaire during May and June 1968. 'With slogans chanted on the street and posters 
REFORMES
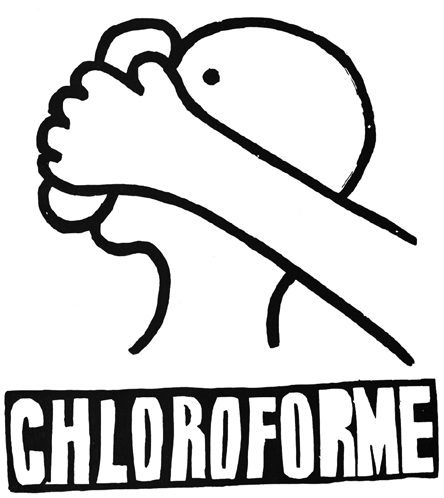

Figure 1

Ironic Image.

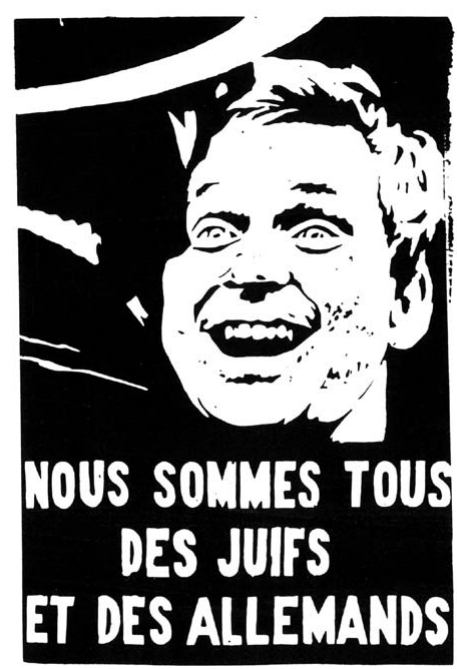

Figure 2

Dialectical Image.

3 Jeffery T. Schnapp, Revolutionary Tides: The Art of the Political Poster 1914-1989 (Milan, Italy: Skira Publications, 2005).

4 Although this typology is the one dealt with in this paper, it is not the only typology possible. The Atelier posters are of a wide variety, and arguments can be made for other categorizations.

5 Cohn-Bendit was an iconic student figure in the May '68 movement, and a FrenchGerman Jew. He was harassed by the police and eventually prohibited from reentering France after a trip to Germany, an abuse of state authority that prompted the making of this poster. plastered on walls, the May '68 movement dripped with ironic reversal: It is forbidden to forbid; soyez realiste, demandez l'impossible.

However, irony was only one of the styles used in the Atelier posters; other posters are what Walter Benjamin would call "dialectical images"-revolutionary images that seek to collapse the temporal distance between past and contemporary struggles to redeem past sacrifices in the name of democracy and freedom. ${ }^{2}$ Produced through a unique spatial practice at the Atelier Populaire, ironic and dialectical posters demonstrate both the tactical style and the democratic commitment of the revolutionary movement.

Almost every revolutionary movement has a corresponding artistic component in the form of revolutionary posters. ${ }^{3}$ This paper argues that many of the posters produced during the May '68 revolutionary movement can be understood in terms of the two related categories proposed. ${ }^{4}$ The first category of posters deploys ironic interruption to challenge the Gaullist state and French society. These images often depict the police and president as oppressors, or, as in Figure 1, they challenge salient concepts (e.g., political reform) to interrupt the status quo. Concepts of reform are usually considered to be progressive, or at worst benign; posters like the one shown in Figure 1 take the concept and portray it in an alternative, contradictory light. Through ironic reversal, the unintended consequences of that "normal" concept become visible; instead of progress, reform is revealed as a social anesthetic.

The second category dealt with in this essay is that of dialectical images-revolutionary posters that collapse the temporal distance between contemporary and past struggles. Dialectical images, like the one in Figure 2, evoke memories of resistance by suggesting the similarity between historical moments or movements and the May ' 68 movement. Consider how the poster in Figure 2 juxtaposes the position of Daniel Cohn-Bendit with the historical position of the Jewish population during World War Two. ${ }^{5}$ Dialectical posters evoke the political memory of resistance and present the movement outside homogenous, linear time, demonstrating both a revolutionary interruption of contemporary political order and the movement's democratic commitment to past struggles.

The tactic of interruption and the movement's democratic commitment were produced in part by the social and spatial practices out of which the movement arose. Revolutionary movements are shaped by the political memories they draw on to challenge the state, as well as by the urban spaces in which they mobilize; the May ' 68 movement in Paris is no exception. Locating such a movement-finding where in time and space a revolutionary movement takes place-is critical. By following the tactics and commitments of the movement through the posters of May ' 68 , as 


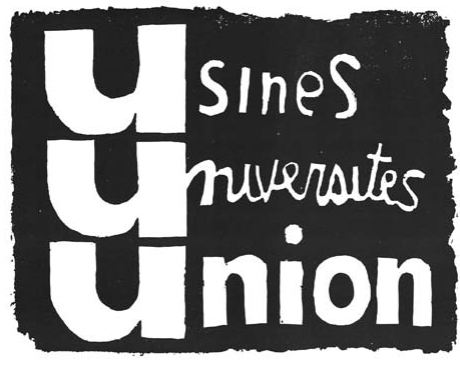

Figure 3

Usines/Universites/Union.
6 For more on movement goals, see Herve Bourges, The French Student Revolt: The Leaders Speak (New York: Hill and Wang, 1968) and Henri Lefebvre, The Explosion: Marxism and the French Revolution (New York: Monthly Review Press, 1969).

7 Gene M. Tempest, Anti-Nazism and the Ateliers Populaires: The Memory of Nazi Collaboration in the Posters of Mai '68, www.docspopuli.org/articles/Paris1968_ Tempest/AfficheParis1968_Tempest.html (accessed February 13, 2012). well as its spatial practice, one can better grasp how the practices of urban space and political memory shape revolutionary movements. Ultimately unsuccessful in overthrowing the state, the May '68 movement in Paris demonstrated the potential of revolutionary action to transform social space while generating a vital political precedent for future movements.

This paper begins with an account of the spatial practice of the revolutionary Atelier. In part one, we lay out the transformation of art students into revolutionary artists, and of their prints into revolutionary posters. We see that the movement on the streets of Paris interrupts the normal cycle of artistic production and everyday life, creating a short circuit between the production of a print and its entry into the realm of the artistic commodity. In addition, taking seriously the decision-making process of artist-revolutionaries reveals a commitment to democratic practice. The second part of the paper analyzes three revolutionary posters for their ironic and dialectical content, noting further that a few of the most compelling posters of the movement demonstrate political memories of resistance. In part three, we analyze one well-remembered, dialectical poster that collapses the temporal distance between Algerian War resistance in the 1950s and 1960s and the May '68 movement. We conclude the paper by briefly assessing the movement's inability to bridge the gap between protesting university students and striking union workers. Although such a union never actually occurred, the movement's commitment to democratic practice succeeded in opening up space for the new social movements of the 1970s. Moreover, it established a new, global, revolutionary memory of radical democracy that we can see at work in contemporary movements, from Occupy to the Arab Spring.

\section{The Story of the Rue du Dragon}

The very first poster created by art students at the École des BeauxArts was a simple lithograph, with the words Usines University, Union (see Figure 3). The poster was the first tangible image that proclaimed the goals of the 1968 student movement—quite simply, the joining together of the workers' movement and the student movement. ${ }^{6}$ This poster was likely printed on quality paper from the university stores, with quality purple lithographic ink, while later posters relied on the end rolls of newsprint donated from sympathetic newspapers and cheap ink gathered from whatever source was available around Paris. ${ }^{7}$ The question following its printing was, "what to do with the posters?" Roughly 50 printed posters were left to be distributed after posting a few on the Atelier walls. The decisions made from this point on illuminate the importance of the print, and its centrality to the movement itself. The posters were taken just a few blocks south of the University, to the rue du Dragon-the street that to this day houses art galleries 
specializing in quality prints. In bringing the posters to the rue du Dragon, the students of the École des Beaux-Arts followed the conventional channels of artistic production and allowed artistic distribution to take its course.

In what might be considered a simplified model of artistic distribution, the artist creates a work of art and then turns that object over to the gallery, which then markets it to potential connoisseurs by displaying the work in catalogs or gallery windows. Our artist-student apparently was thinking in this mode: Create a "revolutionary" poster; take it to a sympathetic gallery to be hung, shown, and admired (and potentially purchased); and with that cash, return to the studio to acquire more paper and ink for the creation of more posters. Thus, the cycle would continue, incorporating this new poster style into the world of the artifactas-art. Evidence of this cycle is built into the urban space of the rue du Dragon. Although only one block long, it has numerous print galleries and is home to both an art school, the Ecole Superior d'Arts Graphique et Architecture Interieur, and a business school, the Ecole Superior de Commerce. With these two schools facing one another on the street, rue du Dragon is situated comfortably between art and commerce.

However, this depiction of the street scarcely satisfies the events of May 15, for the events of that day cannot be contained by a cycle of exchange; instead, something happened on the way to the rue du Dragon. To get there, students of the Beaux-Arts turned and headed down the rue Napoleon, a few short paces to the boulevard St. Germain. But that day, a special reality existed out on the boulevard, a new social practice that literally cut across the cycle of artistic production and commodity exchange: the revolutionary movement. On May 15, the streets were filled with students, workers, immigrants, the unemployed, people who built barricades and who fought with the police. Just to travel a few hundred meters from Beaux-Arts to the rue du Dragon, these prints had to traverse the revolutionary barricade itself. In fact, as the art students traversed the distance between the University and the rue du Dragon, the posters were taken by the movement, and in a moment's time, they were plastered to the wall and distributed to others who would plaster them at other places in the city. In this way, the heat of revolutionary action seemed to rupture the bonds between the print and its role as art-object, transforming it into a revolutionary poster.

This turn of events provides a clear example of revolutionary interruption-interruption not just as a strike, but as the shortcircuit of everyday life, as the interruption of a continual cycle of production and consumption. To be clear, the print created by the students of the Beaux-Arts did not become a revolutionary poster until it was ripped from its normal cycle of artistic commodity and universalized on the street. There, the poster became part of the 
8 Kristin Ross, The Emergence of Social Space: Rimbaud and the Paris Commune (Minneapolis, MN: University of Minnesota Press, 1988), 131

9 The process of lithographic printing involves greasing a portion of a stone or metal block, which when ink is applied creates a positive image, while the negative portions are wetted with water to repel the ink. Each print must be carefully prepared, increasing the time and effort put into each individual print. See Mathilda V. Schwalbach and James A. Schwalbach, Silk-Screen Printing for Artists and Crafstmen (New York: Dover Publications, 1970).

10 Philippe Vermès, "The Late Sixties," in Beauty is in the Street: A Visual Record of the May '68 Uprising, ed. Johan Kugleburg and Phillipe Vermes (London: Four Corners Books, 2011), 9-10.

11 Schwalbach and Schwalbach, Silk Screen Printing; Tempest, Anti-Nazism and the Ateliers Populaires; and Richard G Tansey and Fred S. Kleiner, Gardner's Art Through the Ages, 10th ed. (New York: Harcourt Brace, 1996).

12 Bert Zahn, Screen Process Methods of Reproduction (Chicago: Frederick J. Drake \& Co., 1956) and Schwalbach and Schwalbach, Silk Screen Printing. According to Schwalbach and Schwalbach, "the extreme versatility of the medium has opened completely new possibilities for design and expression... and the inexpensiveness of the equipment needed for small printing has also encouraged experimentation in design," 14 bricolage - a revolutionary image in a kaleidoscope of newly displaced images, each one doing its own work to transform the social practice of the street from one of everyday life into the social practice of a revolutionary situation. ${ }^{8}$ Individually viewed, these posters may not have transformed each individual viewer; but in 1968, their participation in the revolutionary bricolage contributed to a wall of images that informed, educated, and helped direct the movement.

The young artists returning to Beaux-Arts on May 15 conceivably returned not as students but as revolutionaries, seeking to produce more posters, desiring to explore the goals of the movement in ink. But the question they faced was whether they could do so with the lithographic form. The artists realized that the lithograph as a medium was unable to support the needs of the movement. ${ }^{9}$ As a result, at this moment, art production in France was "revolutionized" by the introduction of seriographic techniques. French artists Guy de Rougement and Eric Seydoux had worked with serography in New York-a form of stenciled printing commonly called silk-screening-and were able to teach the collective body of artists how to produce hundreds of prints from a single image. ${ }^{10}$ In the 1960 s, silk-screening was common in the United States in both industrial and artistic print production, including the famous works of Andy Warhol and Roy Lichtenstein, but it was almost unheard of in Parisian print studios. ${ }^{11}$

Unlike lithography, silk-screen printing uses a form of stencil to create a positive image. A silk or nylon screen stretched across a wooden frame is prepared with gum resin or another impermeable substance, and then ink is spread over the entire screen. The negative image gum resin prevents the ink from reaching the paper below, and the artist is left with the positive, inked image. ${ }^{12}$ With this new medium, the revolution had found the means to produce powerful revolutionary posters; and in doing so, the movement transformed the world of French artistic production, spreading an acceptance of seriography as a valid and incredibly versatile technique throughout the French artistic community. With seriography as a revolutionary tactic in France came the birth of the Atelier Populaire as a revolutionary entity. Perfectly positioned to contribute to the revolutionary movement, the Atelier Populaire transformed printmaking in France almost literally overnight.

Not unlike the posters they created, those in the Atelier Populaire tried to represent their revolutionary ideals in the workshop's own internal organization. Students, workers, local artists, volunteers, and amateurs came together at Beaux-Arts and Deco to create revolutionary posters-posters made to inspire and inform revolution. But how was the Atelier to decide which posters would be made, what revolutionary content to inscribe with ink on paper? "All the militants-workers, students, artists, etc.-from the Atelier Populaire meet daily in a General Assembly. The 
work of this assembly is not merely to choose between the designs and slogans suggested for posters, but also to discuss all current political problems. It is mainly during the course of these debates that the political policy of the Atelier Populaire is developed and defined." ${ }^{13}$ These revolutionary councils used a form of democratic procedure to process and decide on content for the posters. Meeting often in the courtyards at the Beaux-Arts and Deco, or alternatively in large workspaces, the group of artists assembled that day debated and deliberated on each of the 350 or so posters that were created between May 15 and mid-June. The Atelier Populaire embraced democratic participation and explored their "policy" by engaging with one another on a level of equal debate. Those for or against a poster could share, argue, and prevent certain posters from being made.

Because decisions to produce posters were made by majority vote, "the direct democracy of the assembly made the poster output politically inconsistent.... Votes depended entirely on the chance composition of the assembly on a given day.... '[C]ertain posters were passed at certain times because there were more proChinese and fewer Trotskyites, or the other way around.'"14 This type of deliberative decision-making was entirely determined by the atelier space-not so much the shape of the building's architecture, what Henri Lefebvre called the "conceived" space, but the unique social practice that existed daily at the Atelier. ${ }^{15}$ The assembled body completed the social practice of revolutionary printmaking differently each day. Different days might have had different practices, depending on who was making the prints that day. As in democratic practice itself, the coherence of expression in the posters is only an illusion. The movement and its posters are a reflection of the democratic practice at work on a given day. Those who participated in the day's action-whether by building a barricade or inking a poster-worked to create the meaning and express the content of the movement.

The spatial practice of the Atelier Populaire presents us with two key insights: The first is the connection between revolutionary posters and revolutionary interruption. While on May 15, art students might not have foreseen that their attempt at poster distribution would be interrupted, the movement on the streets of Paris intersected the everyday cycle of artistic production and consumption, transforming future poster production. The fundamental act of revolutionary interruption translates into many of the revolutionary posters themselves; ironic interruption became a major theme demonstrated in poster content after May 15. The second is that the Atelier General Assembly transmitted its commitment to utopian democratic practice into many of the posters produced. The following two sections develop these themes in detail through an examination of four compelling Atelier posters. Henri Lefebvre, The Production of Space (New York: Blackwell Publishing, 1984). 
Figure 4

La Chienlit.

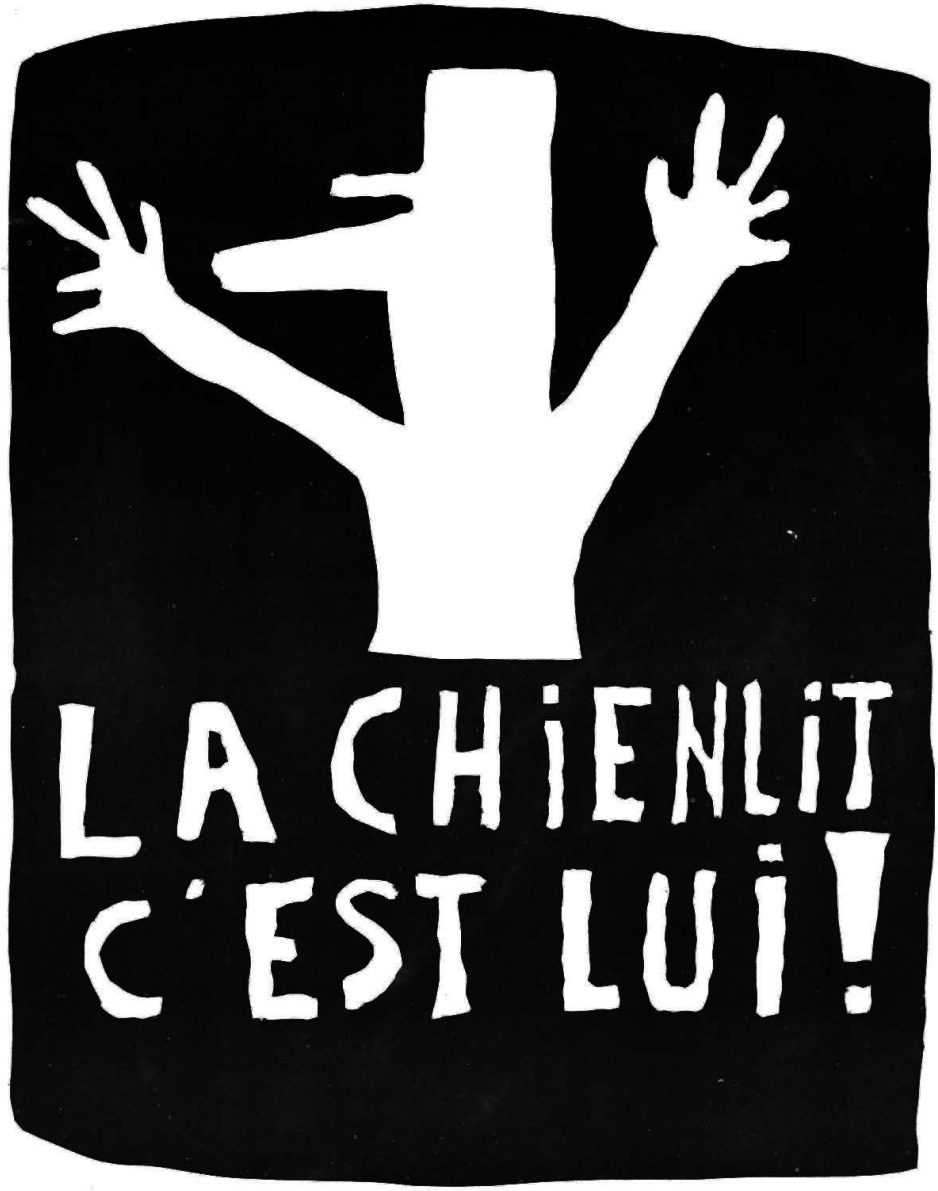

Ironic Interruption to Democratic Commitment

While mocking or deriding the opposition is a normal tactic of social movements, Situationist techniques developed in the 1950s and 1960s demonstrated this tactic in the extreme. ${ }^{16}$ By 1966, students at the University of Strasbourg in eastern France began working with the Situationist International to produce ironic works of art and writing, including the influential tract, On the Poverty of Student Life. ${ }^{17}$ According to Guy Debord, the leading theorist of the Situationist International, ironic acts of diversion have the potential to "upset and overthrow the entire existing order," revealing the society as hollow and thus creating the demand for historical advancement and a true communal society. ${ }^{18}$ The posters and slogans of May 1968 offer many examples of ironic, Situationist tactics, but perhaps none is as memorable or noteworthy as the poster shown in Figure 4. At the outbreak of the May movement and in response to the violence in the first days of street clashes between the police and student protesters, President de Gaulle noted publicly his disapproval of this growing movement, calling the students "la Chienlit" - a uniquely French expression. Although opinions vary about its best idiomatic translation, the 


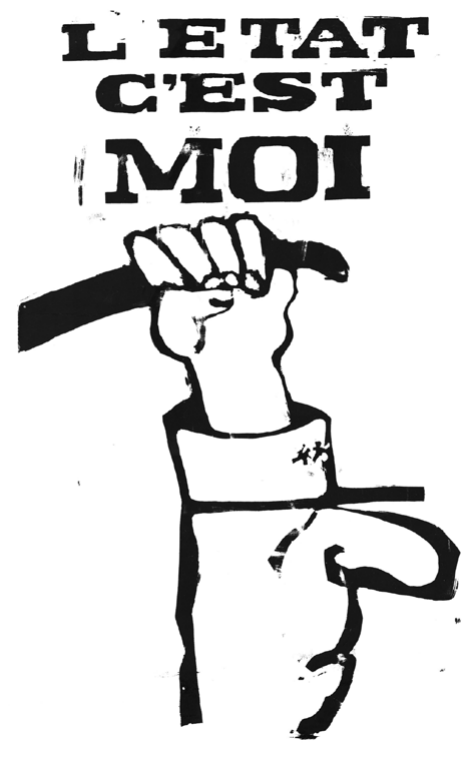

Figure 5

L'Etat c'est moi.
19 Mavis Gallant notes how insulted average Parisian citizens were at de Gaulle's comment. This crude statement did much to undermine popular urban support for de Gaulle in the second and third weeks of May. Mavis Gallant, Paris Notebooks: Essays and Reviews (New York: Random House, 1986), 23-24.

20 Tempest, Anti-Nazism and the Ateliers Populaires. phrase clearly was an insult directed at the movement; de Gaulle was chastising the movement, describing its members as wild creatures that defecate where they sleep. ${ }^{19}$

From the perspective of the student-protesters and sloganeers at the Atelier Populaire who produced the poster in Figure 4, the university (or society at large) was la Chienlit, and the protesters were only calling out in protest over the massively overcrowded conditions at the university. One student artist commented, "[de Gaulle] meant 'it's shit, it's disorder,' and it was very insulting.... Well, when he said that, we had an immediate answer for him.'" 20 The poster interrupts de Gaulle's words of condemnation, transforming them into an ironic attack on the state itself: the image of de Gaulle with arms outstretched in apparent hysteria with the caption "la Chienlit, c'est lui." The rhyming script embraces de Gaulle's condemnation, considers (from the perspective of the student) what "really is" la Chienlit, and flings it back at the source: the French state and its president. The norm in the 1960s was for citizens to refer to political figures like a president with respect, if not admiration. This poster interrupts this normal interpretation of presidential speech, driving the viewer to reconsider the position of the movement vis-à-vis the state.

Furthermore, the rhyme evokes another (in)famous French leader, Louis XIV, who famously said, "l'etat, c'est moi," tying de Gaulle to this deep authoritarian memory. Recalling this memory, the poster in Figure 5 depicts de Gaulle with a "matraque" baton held high, accompanied by the text "l'etat c'est moi." This poster ironically positions de Gaulle as a king, and it borders on the dialectical because it collapses the temporal distance between de Gaulle's state and the absolutist state of the eighteenth century. Such dialectical images seek to promote a connection between the viewer and those past generations who resisted abuse of power. Figure 5 evokes political memory, placing the viewer among the countless people subjected to absolute authority, particularly the absolute authority of the French state. The ironic reversal (and potentially dialectical content) of this image interrupts the everyday understanding of a political or historical concept, inverting and negating its normal meaning and inserting an alternative understanding in its stead. Thus, instead of "l'etat c'est moi" being a phrase out of a history book, its relevance is blasted into the present by an act of dialectical irony.

Dialectical images may have ironic content, but more often they present the democratic commitment of a movement instead. Consider how the poster in Figure 6 performs similar dialectical work to that of Figure 5. We see the same memory called uponthe memory of absolute political authority in the phrase, "L'État c'est...." But unlike the Figure 5 poster, which completes the phrase as a viewer would might normally expect, with an ironic 
juxtaposition of the image of de Gaulle, the Figure 6 poster inserts a new, democratic subject where before there was only ironic expression. The democratic commitment in Figure 6 is palpable; it creates a visual frame, the dark black line embracing the white space of the poster and forming a unified field; the viewer is thus drawn into a sympathetic union with the figure in the foreground. Dialectically, the poster breaks down temporal barriers between the struggles of the present against unjust authority and the past struggles against absolutism. Just as revolutionary interruption transformed an artistic work into a revolutionary poster, the posters of May '68 interrupt the cycle of everyday understanding, forcing a reconsideration of the revolutionary situation. Well-

Figure 6

L'Etat c'est chacun de nous

21 The colonial relationship between France and Algeria began in 1830 with the invasion and annexation of North Africa by a colonial territory-seeking France. The Algerian War proper did not begin until 1954. In correspondence with the general tide of decolonization, reflecting U.S. foreign policy and supported by the international efforts of the United Nations, a general sentiment of independence had been building in the colonial world since the end of World War II. The central organization resisting France in Algeria was the National Liberation Front (FLN). The most well remembered event of the Algerian War was certainly the Battle of Algiers, which lasted from September 30 , 1956, to September 24, 1957. This year is memorialized in the film, Battle of Algiers, by Gillo Pontecorvo. Slightly less well remembered, for interesting and important reasons, are the later events that took place in Paris, not in Algeria. Contrary to a certain popular image, the Algerian war did not end with the Battle of Algiers. Urban protest, strikes, and mobilizations around the Algerian question continued in Paris and Algeria until independence on July 3, 1962. See Alec G. Hargreaves, Memory, Empire and Postcolonialism: Legacies of French Colonialism (New York: Lexington Books, 2005); Thomas G. Weiss, David P. Forsythe, Roger A. Coate, and Kelly-Kate Pease, The United Nations and Changing World Politics (Boulder, CO: Westview Press, 2010); and Martin Evans, The Memory of Resistance: French Opposition to the Algerian War,1954-1962 (New York: Berg Publishers, 1997). constructed posters have the potential to link democratic and historical practice with real contemporary situations, creating a true dialectical image. The next section gives an example of the temporal power of the dialectical image using a poster that recalls Parisian resistance to the Algerian war.

\section{The Dialectical Image of Algerian Resistance}

We see the memory of resistance to the Algerian War appear in the posters of the Atelier Populaire as early as May 19, only a few short days after the switch to seriographic techniques following the events of May 15. ${ }^{21}$ The poster shown in Figure 7 depicts a human form done up in somber blue-a riot policeman holding high a club, a matraque, as if confronting a protester. ${ }^{22}$ The instrument of choice for the riot police was certainly the matraque, a long, balanced bludgeon covered in rubber and an object readily known to protesters: "[During] the year 1968 the word matraquage was suspended between its future connotations and its colonial past: the word derives originally from the Algerian Arabic, matraq, or 'club'.... But the colonial origins of the word remind us of that long national history and of other bloody confrontation in the not so distant past." ${ }^{23}$ Ross refers to the colonial past, particularly in Algeria where the word originated and where the weapon became popular with the security forces that used it against Algerian protesters. ${ }^{24}$

The matraque is an object with a complex past, embedded in the political memory of paramilitary repression in Algeria and in domestic police repression in France as well. Surface level readings of the 1968 revolutionary movement generally focus on the students or the general strike, without recognizing the importance of the Algerian precedent. The revolutionaries of May '68 did not immediately connect with the political memory of Algerian resistance; only after the use of tear-gas by the Compagnies Républicaines de Sécurité (CRS) against the protesters did they make an explicit connection between these two events. In the leaflet, War Gas, handed out in the aftermath of the Night of the Barricades, the 


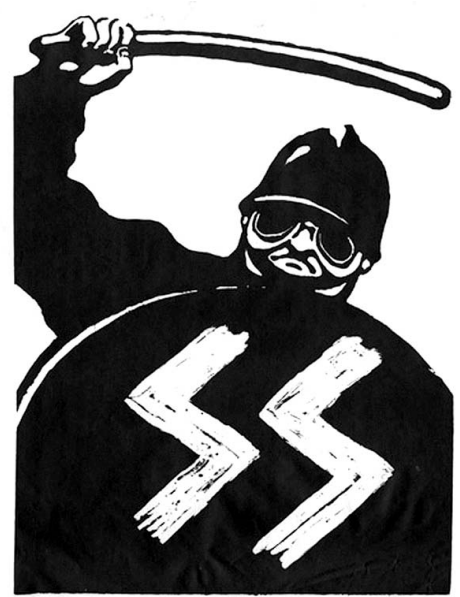

Figure 7

CRS/SS.

22 Second print runs of the poster in Figure 7 include the text, "CRS SS," emblazoned on the policeman's shield. The text and image together recall the memory of the French resistance to Nazi occupation during World War II, further expanding the dialectical content of this potent revolutionary poster. The same slogan, "CRS/SS," was a common chant of anti-Algerian war protesters during the late 1950s and early 1960s. The slogan can even be seen painted on the wall in a Paris street scene in the 1962 film noir, "Les Doulos." The slogan's use in mass media suggests its relevance and recognition in French political memory. See Tempest, Anti-Nazism and the Ateliers Populaires.

23 Ross, May '68 and Its Afterlives, 31-32.

24 Ross also references the contemporary meaning of matraque, which entails being bombarded with commercial images, being figuratively beaten over the head by commodity advertising.

25 Alain Schnapp and Pierre Vidal-Naquet, he French Student Uprising November 1967-June 1968: An Analytic Record (Boston: Beacon Press, 1969), 182

26 Gallant, Paris Notebooks, 9-10. See also Ross, May '68 and Its Afterlives, 33-35.

27 Marcel Proust, 19th Century French novelist, wrote of the varied connections between smell, taste, and sensiation, and the memories of childhood. See his novel, Remembrance of Things Past (New York, NY: Random House, 1981). movement builds a connection between the current struggle on the streets of Paris and the lived memory of Algerian resistance. After listing the types of grenades used by the CRS, the document states "[we] are the guinea pigs for the experiments of a sadistic police who already has Charonne and the tortures in Algeria to its credit." ${ }^{25}$ In her diary account of the events, Mavis Gallant notes that tear-gas permeated the air during the cool, rainy days of May, and she links her own experience of the 1968 revolutionary movement to her memories of the Algerian conflict. Thick in the train stations and thick in the streets, the tear gas was a vivid reminder of urban protest for those Parisians who had lived through demonstrations against the Algerian war. ${ }^{26}$ The vivid connection between the sense of smell and memory, captured so clearly by Proust, served to bond the May '68 movement with the Algeria anti-colonial struggle through the Parisian sense memory of the tear-gas that permeated both events. ${ }^{27}$

In Figure 7, we see the riot policeman (or Organisation de l'Armée Secrète (OAS) soldier?) with matraque held high, ready to bring it down on the wrists, legs, or head of the viewer. The viewer identifies with the victim of the matraque, a fallen student protester or Algerian "ratonné." The CRS policeman looms over the viewer; we almost want to raise our own arm to fend off the boneshattering fall of the matraque. What is at stake with this image? Are we, the matraqué, a student revolutionary, or are we Algerians? Are we beaten in 1968 or in 1958 ? Are we in the rainy streets of the Latin Quarter, or are we in the heat of the Casbah? What this poster tells the viewer is precisely this: These questions do not matter. The image summons political memory, the suppression of Algerian resistance; it eliminates the intervening years and flattens the difference between that memory and the present. The struggle of a past time and place is blasted into the present. This poster literally eliminates a temporal and spatial separation, creating a unique spatial practice where the matraqueurs and matraqués become universal.

Some viewers might see in this work only spoiled, middleclass youth playing at revolution; they minimize the effects of that earlier time, during which the artists were "only" children: "How could they evoke a time and place of which they must have been barely aware, happening as it did in the days of their childhood?" "What right do they have to call on Algeria?" However, in recalling the memories of Algeria, the now-young-adults in the latter movement made explicit the universality of those under the club, even if that universality existed only in the singular moment of the fall of the matraque. The poster and the May '68 movement deployed the memory of Algeria to continue challenging the use of state violence against a domestic population. Although some might note the dramatic difference between the 1968 privileged poster artist and the Algerian resister, the memory 
28 Andrew Feenberg and Jim Freedman, When Poetry Ruled the Streets: The French May Events of 1968 (New York: SUNY Press, 2001), 129.

29 See John Gretton, Students and Workers: An Analytical Account of Dissent in France May-June 1968 (London: MacDonald Publishing, 1969); Richard Johnson, The French Communist Party versus the Students: Revolutionary Politics in May-June 1968 (New Haven, CT: Yale University Press, 1972); and Gallant, Paris Notebooks, 71.

30 Kenward, France and the French, Chapter 16.

31 See Michel de Certeau, The Capture of Speech and Other Political Writings (Minneapolis, MN: University of Minnesota Press, 1997), 11; Julian Bourg, From Revolution to Ethics: May 1968 and Contemporary French Thought (Ithaca, NY: McGill-Queen's University Press, 2007), 19-45; and Ross, May '68 and Its Afterlives, 1-19. of Algeria nevertheless is made concrete once more in the dialectical space of the poster. At least once more, the important struggle for Algerian independence rested at the heart of a revolutionary struggle, combatting the silence of a conformism that threatened to overpower and do away with the memory once and for all.

\section{The Memory of May '68}

Political memories like that of Algerian War resistance are always already embedded in urban space. Memories are inextricably linked with urban social practice. The space of the Atelier Populaire, and these political memories of resistance, gave shape to the May movement. Despite the movement's strong primary space of mobilization on the streets of the Latin Quarter, however, it was unable to establish a secondary space of movement organization in the factories. Although the factories struck in sympathy with the urban protesters, factories were never open to the integration of the student movement and the worker movement. They remained in allied, but in separates spaces. ${ }^{28}$ Many explanations have been offered for this failure to join together; some have been inclined to blame the ossified structures of the major French unions and the Communist Party; others point the finger at the ideological fractionalization and impertinence of the students, or the distrust of the working class for the middle-class students. ${ }^{29}$ This constellation of powers and these divergent goals prevented the integration of worker struggles for social respect and economic benefit with the student revolutionaries' desire for a utopian transformation of the state and society.

By May 30, Charles de Gaulle returned from Germany with military backing and presented himself to a city exhausted by strikes and uncertainty. His coup de théâtre brought hundreds of thousands of previously silent Parisians to the streets in counterprotest, sounding the death-knell of a revolutionary movement already on the wane..$^{30}$ Another two weeks would pass before the streets of the Latin Quarter and its occupied buildings (e.g., the Sorbonne and the École des Beaux-Arts) were finally cleared; the factory strikes around the city and the provinces continued for another month. The movement had failed to transform the state. Even so, revolutionary action transformed cultural and social relations. Democratic speech and democratic participation were the order of the day during the movement's occupation of the Latin Quarter. Once unleashed, this valorization of democratic participation revitalized French political practice. ${ }^{31}$

The form of democratic participation during the May movement nevertheless presented some serious problems. The most glaring of these was the lack of voice given to women and homosexuals. At the bastions of democratic speech like the Sorbonne or the Odeon Theater, space for revolutionary speech was generally reserved for or taken by males. Women were certainly involved in 
32 Claire Duchen, Women's Rights and Women's Lives in France 1944-1968 (New York: Routledge, 1994), 190-212.

33 These two posters could not be more divergent. The first shows a woman throwing a paving stone, with the text, "La beauté est dans la rue," while the second is a stylized image of a naked woman, with the word "Mai" over her crotch. With one a utopian image and the other an objectification of woman, these two posters together demonstrate both the vast potential and the vast problematic of the May '68 movement.

34 See Frederic Martel, The Pink and the Black: Homosexuals in France Since 1968 (Stanford, CA: Stanford University Press, 1999), 13-107; and Michael Sibalis, "The Spirit of May '68 and the Origins of the Gay Liberation Movement" in Gender and Sexuality in 1968: Transformative Politics in the Cultural Imagination, ed. Lessie Jo Frasier and Deborah Cohen (New York: Palgrave McMillan, 2009), 235-55.

35 Sibalis, "The Spirit of May '68 and the Origins of the Gay Liberation Movement," 241.

36 See Ross, May '68 and Its Afterlives, 1-19; Bourg, From Revolution to Ethics, 179-227.

37 Nancy Frasier, "Feminism, Capitalism and the Cunning of History," New Left Review 56 (2009): 97-117. the May revolutionary effort-from fighting with the police on the barricades to occupying the Sorbonne and Odéon-but too often, the women revolutionaries were relegated to those traditional roles assigned by patriarchy of cook, cleaner, care-provider, and sexual object. ${ }^{32}$ Only two revolutionary posters from May '68 depict a female figure, and both of these posters were made in the provincial centers of Montpelier and Toulouse-not the Paris Ateliers. ${ }^{33}$ For a movement that was so skilled in the use of irony, and that could flip the words of a president and the meaning of an entire urban architecture, the inability of the movement's leaders to overturn their own internal representation of the role of women in revolution is deeply ironic.

Furthermore, the democracy of speech did not extend to homosexual students during the occupation of the Sorbonne. For those at the Sorbonne, homosexuality was not a political issue on par with university reform, anti-capitalism, or free love, and other revolutionaries were generally dismissive or hostile to the homosexual members of the movement. ${ }^{34}$ Further irony arises, then, in that gay members of the movement had to remain silent in terms of their sexuality to protect the new-found freedom of occupied spaces. ${ }^{35}$ If the uniqueness of humanity is the human's ability to speak and engage politically, then May ' 68 is perhaps one of the most purely political events in recent history. Yet if the global revolutionary movements of 1968 were concerned with utopian speech, we must point critically to the silences that accompanied this outpouring of speech.

The silences now apparent in May 1968 prevent an unadulterated, utopian memory of that revolution. But at the same time, these silenced ones turn out to find the location from which they can speak in the post-1968 era. After the movement cooled, social space then opened for new growth, and in the newly cleared field of the 1970s, such growth began to be evident precisely in those earlier places of silence-in the lives of women and homosexuals. ${ }^{36}$ The successes of the new social movements of the 1970s and 1980s attest to the influence of utopian speech and the memory of 1968 on the course of future social and revolutionary movements. French students and workers formed the revolutionary core of the movement in 1968 Paris, but the movement empowered women and gays to mobilize for themselves in the coming years.

Social movements certainly call on the memory of May ' 68 , but other social forces have found inspiration in the memory as well. Nancy Frasier points out that many student participants in May '68 went on to play an active role in the neo-liberal expansion of the 1970s and 1980s. ${ }^{37}$ Over time, May '68 students became owners of capital and corporate managers, reorganizing firms from a top-down hierarchical model into ones that embraced quasi-May '68 values, including group participation and the dynamic use of the images in advertising. This combination of the movement's 
artistic freedom of expression with capital accumulation further complicates the memory of May ' 68 . For some, the memory has been embraced as a precedent for current direct action, while for others it was a moment that inspired a reevaluation of contemporary capitalism. Thus, we must point critically to the exploitative dangers of contemporary capitalism, and to the successes of the new social movements of the 1970s; what should be readily apparent is the centrality of May ' 68 in the development of contemporary political practice.

The potent utopian influence of May '68 transcended national boundaries. This study of the May ' 68 revolutionary movement is centered in the urban context of Paris. However, this movement was part and parcel of an international revolutionary movement..$^{38}$ In demonstrating the power of democratic speech and popular urban mobilization to transform society, and potentially to transform the state, the May ' 68 movement established a new and potent political memory. From the struggles of women and gays during the 1970s and 1980s, to the interconnected anti-globalization protests of the 1990s, and on to the contemporary Occupy movements in the United States and the recent Arab Spring revolutions in 2011, we can point to the influence of the volatile year 1968 as a central, antecedent, political memory for current revolutionary struggles. By rearticulating themes of popular speech, democratic participation, and urban social protest, May '68 revolutionaries established a precedent-a political memory that has influenced many contemporary revolutionary movements and that continues to stoke the fires of radical democracy in France and around the world. Although "utopia" may have no clear location in space and time, the utopian vision of the May ' 68 revolutionaries continues to influence the struggles of the contemporary world.

\section{Acknowledgements}

This article was presented at the April 2012 Art and Politics of Irony Conference at McGill University, Montreal. The author is grateful for all the comments and suggestions given there, especially the confirmation of Nancy Frazier's earlier suggestion of the complex outcomes associated with 1968. In addition, thanks go to Norma Claire Morruzi, Issac Balbus, and Victor Margolin at the University of Illinois, Chicago for their help during the writing of the essay.

38 Gurminder K. Bhambra and Ipek Demir, 1968 in Retrospect: History, Theory, Alterity (New York: Palgrave Macmillan, 2009), xi.

\section{Image Credits}

All images sourced with the consent of the publishers, from Johan Kugleburg and Phillipe Vermès. Beauty Is in the Street: A Visual Record of the May '68 Uprising (London: Four Corners Books, 2011). 